\title{
A panel data analysis on the institutional determinants of foreign direct investment inflows: commonalities between India and China
}

\section{Priya Gupta}

Lal Bahadur Shastri Institute of Management, Sector-11, Dwarka, New Delhi - 110075, India Email: priyagupta.1704@gmail.com

\begin{abstract}
Developing as well as developed countries seek to attract Foreign Direct Investment (FDI) due to its multiple advantages for economic development. Several studies have been conducted to find out the economic determinants affecting the FDI inflows across the world but not much has been explored on the institutional factors affecting FDI inflows in emerging economies. Therefore, this paper aims to determine whether institutional quality has any significant impact on the FDI inflows in the specific context of India and China using panel data analysis. Under this technique, all the three regression models, i.e., pooled ordinary least square, fixed effects, and random effects are tested to explore the institutional determinants impacting FDI inflows. The empirical results of the modified random effect model reveal that the country's risk rating on corruption and gender parity index are the two most significant institutional determinants impacting the FDI inflows in both India and China commonly.
\end{abstract}

Keywords: foreign direct investment; FDI; institutional determinants; panel data analysis; gender parity index; corruption; India; China; fixed and random effect model.

Reference to this paper should be made as follows: Gupta, P. (2019) 'A panel data analysis on the institutional determinants of foreign direct investment inflows: commonalities between India and China', Int. J. Comparative Management, Vol. 2, Nos. 3/4, pp.247-272.

Biographical notes: Priya Gupta is a Senior Assistant Professor in the Finance Department at Lal Bahadur Shastri Insitute of Management, New Delhi, India. She received her PhD in Management from Delhi Technological University, Delhi, India. Her research interests include FDI, emerging economies, international finance and econometrics. She has published in journals such as Journal of Advances in Management Research (Emerald), Emerging Economy Studies (SAGE), Journal of Academic Research in Economics (EBSCO) to name a few. She has also presented her research at various conferences organised by Indian Institute of Management (IIM) - Calcutta, Indian Institute of Technology (IIT) - Delhi, University of Delhi (DU), etc. She has worked at reputable organisations namely Apeejay School of Management, New Delhi, India and has a rich experience of more than 11 years in both teaching and research in Finance domain.

This paper is a revised and expanded version of a paper entitled 'Does institutional quality matter for FDI inflows: comparison of India and China using panel data analysis' presented at International Conference on Advances in Management Practices 2019 (ICAMP 2019), Jagan Institute of Management Studies, Delhi, India, 27 April 2019. 


\section{Introduction}

Foreign direct investment (FDI), as the name suggests refers to the investment of capital by an entity in one country, into the business interests in another (foreign) country. Economies that are open for trade and global integration experience more FDIs vis-à-vis the closed economies. The reason for the same being that open economies offer a skilled workforce and growth prospects for the investors and fewer restrictions from the government and other regulatory bodies (Amendolagine et al., 2019; Dunning and Narula, 2003; Pao and Tsai, 2011).

FDI can be made in a variety of ways, including the opening of a subsidiary or associate company in a foreign country, acquiring a controlling interest in an existing foreign company or by means of a merger or joint venture with a foreign company. The choice between setting up a subsidiary/ associate or a branch in a foreign country depends upon the existing regulations in the host as well as home country (Dunning and Narula, 2003; Zebregs and Tseng, 2002).

Looking at the past data, it can be said that FDI flows grew significantly during 1990s. For instance, between 1990-1997, FDI inflows accounted to an average of $13 \%$ a year, however between 1998-2000, they increased to an average of 50\% a year (International Monetary Fund, 2003). One of the reasons for this is the increasing interdependence between nations, leading to rising levels of international trade and hence increasing FDI flows. However, the impact of foreign integration is not even across the globe. There are some regions that have experienced tremendous growth in the FDI inflows whereas on the other hand there are some regions that have not witnessed much change in FDI inflows (Zebregs and Tseng, 2002).

Inward FDI positively affects the host country by accumulation of capital, technical transfer and innovation leading to economic growth. FDI inflows are very beneficial for the developing or emerging economies because it leads to knowledge spillovers (Amendolagine et al., 2019). The question arises as to what exactly drives FDI inflows to the developing countries. Recent studies have been made to find whether institutional quality is one of the driving factors for FDI (Eregha, 2019; Mahbub and Jongwanich, 2019; Mathur and Singh, 2013; Nagaraj, 2003; Pao and Tsai, 2011; Paul and Jadhav, 2019; Wong et al., 2019; Zebregs and Tseng, 2002; Zheng, 2019). Institutional quality refers to the qualitative factors like property rights protection, ease of doing business, ethnic tensions, corruption etc. that have a great impact on the economic growth of a country. The literature shows that institutional quality affects FDI inflows. Sound institutional quality of a country, like political stability, control of corruption, openness to trade etc. positively impacts inward FDI hence driving more foreign investment to the host country whereas poor institutional quality of a country affects the FDI inflows negatively. All these factors are considered by investors while deciding whether to invest in a host country or not.

FDI has also been strongly affecting the two most emerging economies of the world, i.e., India and China in the past years (Mathur and Singh, 2013; Paul and Jadhav, 2019; Yingxi and Hung, 2018; Zheng, 2019). The Indian Government is also opening up gradually in its trade policies like it provides tax and non-tax incentives to foreign investors in specific sectors like electronics. It is also promoting its regional development by inviting foreign investors in the north-eastern regions, Himachal Pradesh and Uttarakhand. For the upliftment of the exporters in the economy and reducing the trade 
deficits, the government also provides incentives for MNCs to set up their units in Special Economic Zones (SEZ), National Investment and Manufacturing Zones (NIMZ) and Export Processing Zones (EPZ). Along with these measures, the state governments in India are also allowed to provide additional investment incentives, which may include providing land at subsidised prices, giving soft loans to manufacturers, cheap availability of power, tax holidays, etc. The role of financial institutions in the Indian economy is also huge in promoting a culture of investment where central government development banks and state industrial development banks offer medium to long term loans for new projects at relatively lower interest rates (Mathur and Singh, 2013; Paul and Jadhav, 2019).

Some more relaxations have been provided by the government in its FDI policy like raising the foreign investment limit, lesser restrictions on modes of investment (i.e., putting many sectors on the 'automatic route' as opposed to the 'government route', which required prior approval from the Foreign Investment Promotion Board (FIPB)). More investment in sectors like real estate, private banking, defence, civil aviation, single brand retail and news broadcasting is likely to be seen with such relaxations been granted by the government. Moreover, foreign firms are now also allowed to invest in creating railway networks and supplying bullet trains. Newer policies of the present government like Make in India, Digital India, Skill India, etc. are also some positive moves in promoting FDI.

Earlier findings suggest that probably the restrictive FDI policies of the Indian Government were a major reason for restraining the foreign players to enter into the Indian market and operate freely. However, it is to be noted that since 2014, more liberalised trade policies and campaigns like Make in India have induced more foreign participants to invest in India. This is also reflected in the increased levels of FDI inflows from 2014-2016. The highest levels of FDI inflows were achieved by India in 2016 only, i.e., 44.46 billion USD.

Neighbouring country China is among the top most countries in the world for attracting FDI inflows which is due to its economic growth measured in terms of GDP growth rate, high capital formation rate, and high industrial production index among many others (Yingxi and Hung, 2018; Zheng, 2019). Therefore, it is equally relevant to discuss its success story in terms of its qualitative factors contributing to increased FDI inflows and higher foreign participation vis-à-vis India.

The Government of China has a very clear policy of investment in which it has segregated the sectors where it wants to promote FDI and where it is prohibited. The sectors which are in need of FDI as per the government are: advance technology, innovative equipment manufacturing, services sector, recycling of waste, clean and green production technologies, the use of renewable energies and environmental protection. On the other hand, those sectors which already have a relatively strong production capacity and are in use of advanced technologies are prohibited for FDI.

In addition to the above policy, the Government of China also discourages foreign investment in sectors which are deemed to be keys for social stability, sectors where domestic firms are to be developed into globally competitive MNCs and sectors which are running wholly by the support of sanctions by the government. The government also prohibits investments in currency market and real estate where the intention of foreign investor is to make quick gains and indulge into speculative activities. Moreover, the government has also strictly indicated that it plans to restrict FDI in resource intensive and highly pollution emitting industries. 
While lot of literature is available on the studies related to determinants of FDI inflows, most of them focus on either the analysis of a single country or are based on conceptual frameworks formulated to analyse FDI inflows in developed countries of the world (Eregha, 2019; Mahbub and Jongwanich, 2019; Mathur and Singh, 2013; Nagaraj, 2003; Paul and Jadhav, 2019; Wong et al., 2019; Zheng, 2019). Also, most of the studies delve upon the economic determinants affecting FDI inflows. However, nothing much has been discussed whether the logic postulated in previous studies can be directly applied to FDI inflows in emerging economies like India and China and also the qualitative part of impacting FDI inflows remains unexplored (except for few studies: Yingxi and Hung, 2018). Therefore, this study adds not just to the literature of FDI but also has significant implications for the policy makers and researchers dwelling upon this area.

\subsection{An overview of FDI inflows in India and China}

Many comparisons have been made between India and China, probably because of the same challenges that the two countries have faced (Yingxi and Hung, 2018). In recent times FDI and economic growth have been common topics of discussion with respect to the two most emerging economies of the world. Both these economies have adopted market oriented policies for attracting inward FDI. These economies are becoming integrated with the global economies through open international trade and capital flows.

Table 1 shows the annual FDI inflows in India and China in US billion dollars from 2007-2017.

Table 1 Annual FDI net inflows in India and China (2007-2017, in US\$ billion)

\begin{tabular}{lcc}
\hline Year & India & China \\
\hline 2017 & 39.9661 & 168.2236 \\
2016 & 44.4586 & 174.7496 \\
2015 & 44.0095 & 242.4893 \\
2014 & 34.5766 & 268.0972 \\
2013 & 28.1530 & 290.9284 \\
2012 & 23.9957 & 241.2139 \\
2011 & 36.4987 & 280.0722 \\
2010 & 27.3969 & 243.7034 \\
2009 & 35.5814 & 131.0571 \\
2008 & 43.4063 & 171.5347 \\
2007 & 25.2277 & 156.2493 \\
\hline
\end{tabular}

Note: Own compilation based on the data extracted from World Development Indicators 2019 (World Bank)

With the liberal trade regimes followed by the Chinese economy, the maximum FDI inflows have been coming to China as compared to other developing countries of the world. It remains the leader in getting highest FDI inflows since 1985 to 2017. But, if the trend of only last decade is seen, the growth made by the Indian economy in terms of FDI inflows is also noticeable, i.e., $58.42 \%$ which is the maximum among other developing countries. 


\subsection{Relevance of the study}

Both India and China have emerged as the fastest developing economies of the world. Significant infrastructural and other favourable economic and institutional changes have led these countries to this path of development. Both the countries have a momentous influence on regional and global affairs discussed at the international platforms. Both countries are a part of the G-20 group. Both India and China are not just developing or newly industrialised economies, but they are also classified as largest (in terms of surface area and population size) and fastest- growing economies. These reasons make India and China as the most attractive destinations for capital inflows (especially in the form of FDI).

Among 122 countries of the world (as per available data), both the countries are in the top 15 destinations of the world in attracting FDI inflows (China - 3rd and India - 12th). Among 188 countries of the world (as per available data), in terms of absolute GDP levels, both these countries are among the top 35 positions (China - 2nd and India - 6th). These facts clearly indicate some correlation between the GDP levels and FDI inflows (used as a proxy throughout the paper in place of FDI net inflows) in these countries and that is how this present study becomes relevant for the policy makers of these countries.

\section{Literature review}

By providing technical know-how, capital and access to diverse markets for production of goods and services, FDI is assumed to bring about economic growth in the developing countries. However host countries find it challenging to attract FDI as there is a need to identify the factors impacting FDI inflows and then make the necessary improvements, if any, on those factors that are the key drivers of FDI.

There are several studies which have analysed the determinants of FDI inflows for individual countries or groups of countries that are part of developing or developed markets. A brief summary of such studies is presented in this section.

\subsection{Studies in the context of developing countries}

According to Mishra and Daly (2007) source country's outward FDI is very much impacted by the quality of institutions in the host country. Factors like firmness and fairness of the legal system, adherence to law, bureaucratic quality and a stable government in host country are significant drivers of FDI. Chaib and Siham (2014) observed that economic institutional quality and voice and accountability are major determinants of FDI inflows in Algeria. Various studies pertaining to specific developing countries include studies by Esew and Yaroson (2014) who emphasised on political stability and corruption as the most instrumental factors for attracting FDI in Nigeria. Another study by Walsh and Yu (2010) shows that it is not only a country's income levels and exchange rate valuations that affect FDI flows into the emerging markets but also the development indicators like financial base and admissions to school and institutional factors like independence of the judiciary and flexibility at workplace that are also very significant in attracting FDI. 
A study by Fiodendji (2013) to find out the effects of institutional determinants for FDI inflows in Sub Saharan African Countries indicated that government stability, profile investment, democratic accountability, law and order, and control of corruption are significant in determining the FDI inflows in the countries. Bon (2014) while studying the effects of qualitative factors on FDI in provinces of Vietnam concluded that in the total sample of all 43 provinces the strength of qualitative determinants has significantly positive effects on FDI inflows; however while examining the sub sample, the impact of institutional quality on FDI has not been significantly positive in all the regions. In another study by Bénassy-Quéré et al. (2007) on the determinants of FDI in developing countries factors like tax structure, relaxations to start a company, corruption control, transparency, contract law, property rights protection, judicial efficiency and prudential standards were examined and public efficiency in broad sense, was found out to be a major determinant of FDI. Kurul and Yalta (2017) while studying the relationship between FDI inflows and supervision of corruption, state effectiveness, stability of the political systems and absence of rage and terrorism, quality of rules and regulations, adherence to law, and voice and accountability in the 113 developing countries found out that countries having better institutional quality attract more FDI. Fakher (2014) in his study concluded that factors like accountability, rule of law, corruption control, regulatory quality, etc. are the most important factors in determining inward FDI.

A study by $\mathrm{Hu}$ (2007) concluded that higher literacy and education rates in China attract more FDI inflows. In the context of Pakistan, Rehman (2009) highlighted the importance of political stability and availability of energy to the MNEs to invite them to invest their capital for a long run. In a research on African countries, Musila and Sigue (2006) emphasised on bringing economic reforms and policy changes in the host country so as to be a favourite destination of investment by MNCs. In addition to this, Asiedu (2002) said that by providing better infrastructural facilities and following liberalised trade regimes, host countries like Africa may attract more FDI inflows. Almost similar conclusions were drawn in the context of Russia by various researchers. In a study conducted by Jones et al. (2000), national infrastructure facilities and transparent government policies were cited as the most crucial determinants of attracting more FDI inflows. Another study by Popovich (2007) mentioned political risk as the most important deterrent towards bringing FDI inflows. Bergsman et al. (1999) in an earlier study on Russia also focused on having a more modern approach towards FDI, i.e., by following liberalised trade regimes to the maximum extent possible. The overall environment of a host country in terms of stable government policies, transparent law and order mechanism, better infrastructural facilities (e.g., energy, transportation, etc.) and a clear focus on education and health sectors makes a difference in bringing these developing countries on the top list of destinations attracting maximum FDI inflows.

\subsection{Studies in context of group of countries}

Sabir et al. (2019) in a recent study found that corruption, effectiveness of government, political stability, quality of rules, regulations and legal systems, voice and accountability of FDI are significant factors influencing FDI inflows in developed and developing countries. Though, the magnitude of their impact on developed countries is more as compared to the developing countries. Another very recent study by Paul and Jadhav (2019) on the institutional determinants impacting FDI inflows in 24 emerging countries explored that quality of infrastructure, tariff and non-tariff barriers, political stability, 
quality of rules and regulations and corruption levels have a significant impact on FDI inflows. Exploring the determinants of FDI for group of 110 developed and developing countries, Peres et al. (2018) concluded that institutional quality significantly influences the FDI inflows in developed countries vis-à-vis an insignificant impact in case of developing countries. They further proved that the governance indicators tend to be key determinants for attracting FDI inflows. Jadhav (2012) concluded that although economic factors (market size, trade openness, natural resources) are the most significant determinants of FDI inflows to BRICS economies, however analysis of empirical data also indicates that institutional factors such as country's high indulgence into foreign trade, natural resource availability, rule of law and voice and accountability are also statistically significant in determining FDI inflows in BRICS (Brazil, Russia, India, China and South Africa) economies. In a study conducted by Assadzadeh and Pourqoly (2013) to find out the relationship between FDI, institutional quality and poverty in case of MENA countries, it was found that sound institutional quality in a country has positive effects on FDI inflows which ultimately help to reduce poverty and improve welfare of people. Rule of law was considered to study institutional quality in the countries.

A study conducted by Daude and Stein (2007) on 152 host countries also concludes a positive relationship between better institutions and FDI inflows. Factors like unpredictable policies, excess of regulations, and not proper enforcement of property rights play a crucial role in reducing the FDI flows. Akpan et al. (2014) while studying the BRICS and MINT (Mexico, Indonesia, Nigeria and Turkey) countries found out that the size of market, and availability of infrastructure and trade openness were significant in determining the increase in FDI inflows. In yet another study conducted on MINT countries by Fanbasten and Escobar (2016), other factors also came up as determinants of FDI including political stability, no trade barriers by the host country and stable institutions in the country.

A study based on institutional determinants by Talamo (2011) revealed corporate governance and institutional quality as the most important factor of FDI. Seyoum and Manyak (2009) concluded that public and private transparency can act as the strong reason for rising FDI inflows in developing countries. In another study on developing countries, Busse and Hefeker (2005) showed that a stable government, absence of internal conflict and ethnic tensions, basic democratic rights and a proper law and order mechanism leads to better FDI inflows. Wint and Williams (2002) also supported stable government policies as a reason for having more FDI flows into the host country. Miyamoto (2003) highlighted that an economy having a focused approach for human capital formation (i.e., by making both public and private investments on improvising the standard of living, education and health of man power) attracts more MNCs to invest their capital for long run in the form of FDI. Another perspective for attracting more FDI inflows in the host country was presented by Maskus (2000) who stressed on the protection of intellectual property rights (IPRs) of the MNCs bringing not just capital but also production technologies to the host country. He emphasised on the need of adhering to various multilateral agreements [like multilateral agreement on trade-related aspects of intellectual property rights (TRIPS)] to significantly strengthen the IPR regime in the host country.

Thus, it can be seen from the above literature that there may be various studies regarding the institutional quality as a determinant of FDI inflows in the context of both 
developed and developing economies but there is hardly any study which explores such determinants of FDI inflows in the context of India and China.

After reviewing the literature in respect of determinants of FDI, it can be concluded that there has not been a consensus between the researchers in determining the impact of various institutional factors on FDI. Each study brought about some different variables responsible for attracting FDI in a given country. This necessitates reinvestigation of factors influencing FDI in case of India and China.

\subsection{Research gap}

From the above review of literature, it has been observed that researchers agreed about the impact of many determinants on FDI but there is lack of uniformity of the opinion regarding the influence of some determinants that have not been researched much in the past. Also, most of the studies reviewed in the above section focus majorly on developing economies and group of economies (Eregha, 2019; Mahbub and Jongwanich, 2019; Mathur and Singh, 2013; Paul and Jadhav, 2019; Wong et al., 2019). However, not many studies have been conducted in context of Asian countries particularly India and China (except for few comparative studies: Yingxi and Hung, 2018). Therefore, this necessitates reinvestigation of all these institutional factors influencing FDI inflows in the specific context of India and China.

\section{Research methodology}

\subsection{Objective}

The objective of this study is to determine the most significant institutional determinants impacting FDI inflows in India and China.

\subsection{Period}

The study has been conducted on annual data of ten years period from 2007 to 2017 . This is because of the paucity of data for all fifteen variables chosen for the study; these have been shortlisted as per the uniform availability of data points.

\subsection{Data sources}

Due to non-availability of the entire dataset on institutional variables in the earlier mentioned data sources, i.e., World Development Indicators (WDI) issued by World Bank, country risk ratings are used as a proxy (Malhotra et al., 2014; Savoiu et al., 2013; Popa, 2012; Samara, 2012; Basu et al., 2011). The data on country risk ratings, measuring the institutional quality of these countries, is obtained from the International Country Risk Guide (ICRG) published by the Political Risk Services (PRS) Group, USA. The PRS Group, USA, founded in 1979, is largely used as the most authentic source by investment firms, colleges and universities, multilateral agencies like IMF, etc. The same data source has been used by Arbatli (2011), David et al. (2011), Kinoshita (2011) in their respective research works conducted with IMF. 


\subsection{Variables}

On the basis of the literature reviewed in the previous section, a set of variables have been chosen that may have an impact on the FDI inflows into a country. The dependent variable in this study is the FDI inflows in US billion dollars and the independent variables that are expected to determine FDI inflows are carefully chosen on the basis of availability of data for the selected period (Table 2). The dataset consists of annual data from 2007-2017 for both India and China.

Table 2 Independent variables used in the study and their measurement

\begin{tabular}{|c|c|c|}
\hline $\begin{array}{l}\text { Variable } \\
\text { symbol }\end{array}$ & Variable name & Measurement \\
\hline $\mathrm{Y}$ & $\begin{array}{l}\text { Foreign direct } \\
\text { investment }\end{array}$ & \#Net inflows of FDI in current billion US dollars \\
\hline $\mathrm{X} 1$ & Corruption & $\begin{array}{l}\text { \#Risk rating based on assessment of corruption within the } \\
\text { political system. Maximum points: } 6 \text {, minimum Points: } 0\end{array}$ \\
\hline $\mathrm{X} 2$ & Ethnic tensions & $\begin{array}{l}\text { \#Risk rating based on assessment of the degree of tension } \\
\text { within a country attributable to racial, nationality, or } \\
\text { language divisions. Maximum points: } 6 \text {, minimum points: } \\
0\end{array}$ \\
\hline $\mathrm{X} 3$ & $\begin{array}{l}\text { Logistics } \\
\text { performance index: } \\
\text { ability to track and } \\
\text { trace consignments }\end{array}$ & $\begin{array}{l}\text { *Risk rating based on the most important export and } \\
\text { import markets of the respondent's country, and } \\
\text { neighbouring countries that connect them with } \\
\text { international markets. Maximum points: } 5 \text { (very high), } \\
\text { minimum points: } 1 \text { (very low) }\end{array}$ \\
\hline $\mathrm{X} 4$ & $\begin{array}{l}\text { Gender parity index } \\
\text { (GPI): school } \\
\text { enrolment, tertiary } \\
\text { (gross) }\end{array}$ & $\begin{array}{l}\text { * Gender parity index for gross enrolment ratio in tertiary } \\
\text { education is the ratio of women to men enrolled at tertiary } \\
\text { level in public and private schools. A GPI of less than } 1 \\
\text { suggests girls are more disadvantaged than boys in learning } \\
\text { opportunities and a GPI of greater than } 1 \text { suggests the other } \\
\text { way around. }\end{array}$ \\
\hline $\mathrm{X} 5$ & Bureaucracy quality & $\begin{array}{l}\text { \#Risk rating based on sub components: the institutional } \\
\text { strength and quality of the bureaucracy. Maximum points: } \\
4 \text {, minimum points: } 0\end{array}$ \\
\hline $\mathrm{X} 6$ & External conflict & $\begin{array}{l}\text { \#Risk rating based on sub components: war, cross-border } \\
\text { conflict and foreign pressures. Maximum points: } 12, \\
\text { minimum points: } 0\end{array}$ \\
\hline $\mathrm{X} 7$ & Government stability & $\begin{array}{l}\text { \#Risk rating based on sub components: government unity, } \\
\text { legislative strength and popular support. Maximum points: } \\
\text { 12, minimum points: } 0\end{array}$ \\
\hline
\end{tabular}

Notes: Own compilation based on extensive literature review.

\#Extracted from the ICRG Methodology provided on http://www.prsgroup.com/

ICRG_methodology.aspx where points are assigned by ICRG, PRS Group, USA

editors on the basis of a series of pre-set questions for each risk component

(accessed on 18 May 2019). Maximum points of each risk ratings equates to very

low risk whereas minimum points means very high risk.

*Extracted from World Development Indicators published by World Bank where

points are assigned by various compiling agencies on the basis of rounds of

surveys conducted with targeted respondents (accessed on 3 June 2019).

Maximum points and minimum points assigned are explained in Table 2. 
Table 2 Independent variables used in the study and their measurement (continued)

\begin{tabular}{|c|c|c|}
\hline $\begin{array}{l}\text { Variable } \\
\text { symbol }\end{array}$ & Variable name & Measurement \\
\hline $\mathrm{X} 8$ & Internal conflict & $\begin{array}{l}\text { \#Risk rating based on sub components: civil war/coup } \\
\text { threat, terrorism/political violence and civil disorder. } \\
\text { Maximum points: } 12 \text {, minimum points: } 0\end{array}$ \\
\hline X9 & Law and order & $\begin{array}{l}\text { \#Risk rating based on sub components: strength and } \\
\text { impartiality of the legal system and popular observance of } \\
\text { the law. Maximum points: } 6 \text {, minimum points: } 0\end{array}$ \\
\hline $\mathrm{X} 10$ & Military in politics & $\begin{array}{l}\text { \#Risk rating based on assessment of threat of military } \\
\text { take-over. Maximum points: } 6 \text {, minimum points: } 0\end{array}$ \\
\hline $\mathrm{X} 11$ & Religious tensions & $\begin{array}{l}\text { \#Risk rating based on assessment of threat by a single } \\
\text { religious group that seeks to replace civil law by religious } \\
\text { law. Maximum points: } 6 \text {, minimum points: } 0\end{array}$ \\
\hline $\mathrm{X} 12$ & $\begin{array}{l}\text { Socioeconomic } \\
\text { conditions }\end{array}$ & $\begin{array}{l}\text { \#Risk rating based on sub components: unemployment, } \\
\text { consumer confidence and poverty. Maximum points: } 12 \text {, } \\
\text { minimum points: } 0\end{array}$ \\
\hline $\mathrm{X} 13$ & $\begin{array}{l}\text { Business extent of } \\
\text { disclosure index }\end{array}$ & $\begin{array}{l}\text { *Risk ratings based on the extent to which investors are } \\
\text { protected through disclosure of ownership and financial } \\
\text { information. Maximum points: } 10 \text { (more disclosure), } \\
\text { minimum points: } 0 \text { (less disclosure) }\end{array}$ \\
\hline $\mathrm{X} 14$ & $\begin{array}{l}\text { Logistics } \\
\text { performance index: } \\
\text { overall }\end{array}$ & $\begin{array}{l}\text { *Risk ratings based on perception about the country's } \\
\text { logistics. Maximum points: } 5 \text { (better performance), } \\
\text { minimum points: } 1 \text { (worst performance). }\end{array}$ \\
\hline $\mathrm{X} 15$ & $\begin{array}{l}\text { Quality of port } \\
\text { infrastructure }\end{array}$ & $\begin{array}{l}\text { *Risk ratings based on business executives' perception of } \\
\text { the country's port facilities. Maximum points: } 7 \\
\text { (well developed), minimum points: } 1 \text { (extremely } \\
\text { underdeveloped). }\end{array}$ \\
\hline
\end{tabular}

Notes: Own compilation based on extensive literature review.

\#Extracted from the ICRG Methodology provided on http://www.prsgroup.com/ ICRG_methodology.aspx where points are assigned by ICRG, PRS Group, USA editors on the basis of a series of pre-set questions for each risk component (accessed on 18 May 2019). Maximum points of each risk ratings equates to very low risk whereas minimum points means very high risk. *Extracted from World Development Indicators published by World Bank where points are assigned by various compiling agencies on the basis of rounds of surveys conducted with targeted respondents (accessed 3 June 2019). Maximum points and minimum points assigned are explained in Table 2 .

\subsubsection{Explanation of the variables}

\subsubsection{Dependent variable}

- $\quad F D I(Y)$ : proxy-FDI net inflows: data on FDI flows are presented on net bases (capital transactions' credits less debits between direct investors and their foreign affiliates). Net decreases in assets or net increases in liabilities are recorded as credits, while net increases in assets or net decreases in liabilities are recorded as debits. Hence, FDI flows with a negative sign indicate that at least one of the components of FDI is negative and not offset by positive amounts of the remaining components. These are instances of reverse investment or disinvestment. 


\subsubsection{Independent variables}

1 Corruption (X1): corruption is that evil in any economy which not just distorts the outer reputation of a country but also ruins the roots of that nation. It may exist in various forms in any economy distorting its financial environment leading to discontentment in the minds of foreign investors (see Malhotra et al., 2014; Daude and Stein, 2007; ICRG Methodology, http://www.prsgroup.com/ICRG_ methodology.aspx).

2 Ethnic tensions (X2): this refers to the inherent tensions existing in any economy in terms of racial discrimination, nationality or language differences. This creates an unhealthy environment in which the MNCs from foreign countries might not like to operate (see Malhotra et al., 2014; Daude and Stein, 2007; ICRG Methodology, http://www.prsgroup.com/ICRG_methodology.aspx).

3 Logistics performance index - ability to track and trace consignments (X3): the Logistics Performance Index is an interactive benchmarking tool created to help countries identify the challenges and opportunities they face in their performance on trade logistics and what they can do to improve their performance. It is the ability to track and trace consignments (WDI, 2019).

4 Gender parity index-gross enrolment ratio in tertiary education (X4): it is the ratio of women to men enrolled at tertiary level in public and private schools. Eliminating gender disparities in education would help increase the status and capabilities of women (WDI, 2019).

5 Bureaucracy quality (X5): it refers to the institutional strength and quality of the bureaucracy in any country. This has a direct impact on the policy measures taken by a newly elected government. A high risk country usually faces traumatic changes in the policies as well as the administrative controls with the change in the government which in turn adversely impacts the foreign investors to operate in that country (see Malhotra et al., 2014; Daude and Stein, 2007; ICRG Methodology, http://www.prsgroup.com/ICRG_methodology.aspx).

6 External conflict $(X 6)$ : it may exist in an economy in the form of foreign pressures for trade restrictions, withholding of aids and sanctions, threat of war or cross-border conflicts. This discourages the foreign investors to allocate their economic resources in such countries which are prone to such risks (see Malhotra et al., 2014; Daude and Stein, 2007; ICRG Methodology, http://www.prsgroup.com/ICRG methodology.aspx).

7 Government stability (X7): it is the measure of stability of the elected government and its commitment in implementing the policies declared by it in due course of time. A conflict from the opposition may dwindle with the position of the present government creating an unstable environment for not just the domestic companies but also for the foreign counterparts (see Malhotra et al., 2014; Daude and Stein, 2007; ICRG Methodology, http://www.prsgroup.com/ICRG_methodology.aspx).

8 Internal conflict (X8): this refers to assessment of any possibility of civil war, civil disorder or terrorism within the country leading to a situation of unrest in the economy. This obviously acts as a deterrent to the foreign investors to invest in such 
countries (see Malhotra et al., 2014; Daude and Stein, 2007; ICRG Methodology, http://www.prsgroup.com/ICRG_methodology.aspx).

9 Law and order (X9): it measures the strength and impartiality of the legal system and also assesses the observance of law in terms of crime rate. Country having a strong judicial system attracts more foreign investment vis-à-vis a country having high illegal mechanisms in place (see Malhotra et al., 2014; Daude and Stein, 2007; ICRG Methodology, http://www.prsgroup.com/ICRG_methodology.aspx).

10 Military in politics (X10): a threat of military takeover may represent a high risk as it is an indication that the government is unable to function effectively and therefore the country has an uneasy environment for foreign businesses (see Malhotra et al., 2014; Daude and Stein, 2007; ICRG Methodology, http://www.prsgroup.com/ ICRG_methodology.aspx).

11 Religious tensions (X11): This is the risk of a single religious group dominating the governance of the whole country. In other words, some inexperienced people trying to impose unnecessary policies through civil war leading to an uncertain investment climate and discouraging both domestic and foreign investors to remain invested in such countries (see Malhotra et al., 2014; Daude and Stein, 2007; ICRG Methodology, http://www.prsgroup.com/ICRG_methodology.aspx).

12 Socio-economic conditions (X12): these conditions encompass the basic problems at the root level in most of the developing nations. This includes poverty, unemployment, inequality of income, confidence of consumer in the market which affects the individuals of the economy and the society at large (see Malhotra et al., 2014; Daude and Stein, 2007; ICRG Methodology, http://www.prsgroup.com/ ICRG_methodology.aspx).

13 Business Extent of disclosure index (X13): The data measures the by- laws to be followed by the businesses, outcomes of the regulatory procedures, and also the extent of legal protection of property, the rigidness related to employment regulations and tax liabilities on businesses. The primary principle of this data is that all economic activities requires good rules and regulations that are well-organised, understandable and implemented (WDI, 2019).

14 Logistics performance index-overall (X14): the ratings are based on the efficiency of customs clearance process, quality of trade and transport- related infrastructure, ease of arranging competitively priced shipments, and frequency with which shipments reach the consignee within the scheduled time, etc. (WDI, 2019).

15 Quality of port infrastructure (X15): well-developed infrastructure reduces the effect of distance between regions, integrating the national market and connecting it at low cost to markets in other countries and regions. In addition, the quality and extensiveness of infrastructure networks significantly impact economic growth and reduce income inequalities and poverty in a variety of ways. It enables entrepreneurs to get their goods and services to market in a secure and timely manner and facilitate the movement of workers to the most suitable jobs (WDI, 2019). 


\section{Descriptive statistics, model and hypotheses}

The study has tried to ascertain the institutional determinants impacting FDI inflows in both India and China commonly, for which the following model has been tested with the help of 15 independent variables and one dependent variable on the basis of extensive review of literature discussed in Section 2 earlier.

$$
\begin{aligned}
\mathrm{Y}_{\text {it }}= & \alpha+\beta_{1} \mathrm{X} 1_{\text {it }}+\beta_{2} \mathrm{X} 2_{\mathrm{it}}+\beta_{3} \mathrm{X} 3_{\mathrm{it}}+\beta_{4} \mathrm{X} 4_{\mathrm{it}}+\beta_{5} \mathrm{X} 5_{\mathrm{it}}+\beta_{6} \mathrm{X} 6_{\mathrm{it}}+\beta_{7} \mathrm{X} 7_{\mathrm{it}} \\
& +\beta_{8} \mathrm{X} 8_{\mathrm{it}}+\beta_{9} \mathrm{X} 9_{\mathrm{it}}+\beta_{10} \mathrm{X} 10_{\mathrm{it}}+\beta_{11} \mathrm{X} 11_{\mathrm{it}}+\beta_{12} \mathrm{X} 12_{\mathrm{it}}+\beta_{13} \mathrm{X} 13_{\mathrm{it}} \\
& +\beta_{14} \mathrm{X} 14_{\mathrm{it}}+\beta_{15} \mathrm{X} 15_{\mathrm{it}}+\mu_{\mathrm{it}}
\end{aligned}
$$

The explanation of all the dependent and independent variables ( $\mathrm{Y}$ and $\mathrm{X} 1-\mathrm{X} 15$ respectively) used in the above model is mentioned in Section 3.4.1 above, whereas $\alpha$ is the intercept term and $\mu_{\mathrm{it}}$ is the stochastic disturbance term of the model.

As part of preliminary investigation, the descriptive statistics of the variables used in the study have been presented in Table 3 .

Table 3 Descriptive statistics of independent variables in the study

\begin{tabular}{lccccc}
\hline Variable & Observation & Mean & $\begin{array}{c}\text { Standard } \\
\text { deviation }\end{array}$ & Minimum & Maximum \\
\hline X1 & 20 & 2.3670 & 0.2490 & 1.5000 & 2.5000 \\
X2 & 20 & 3.2611 & 0.8240 & 2.5000 & 4.5000 \\
X3 & 20 & 3.2485 & 0.2223 & 2.8200 & 3.5500 \\
X4 & 20 & 1.0191 & 0.0446 & 0.9823 & 1.1191 \\
X5 & 20 & 2.5000 & 0.5129 & 2.0000 & 3.0000 \\
X6 & 20 & 9.8048 & 0.2447 & 9.0000 & 10.0000 \\
X7 & 20 & 9.4217 & 1.3439 & 7.0000 & 11.0000 \\
X8 & 20 & 8.6382 & 1.3890 & 6.5000 & 10.5000 \\
X9 & 20 & 4.2500 & 0.2564 & 4.0000 & 4.5000 \\
X10 & 20 & 3.5000 & 0.5129 & 3.0000 & 4.0000 \\
X11 & 20 & 3.7500 & 1.2824 & 2.5000 & 5.0000 \\
X12 & 20 & 6.5296 & 1.6892 & 4.5000 & 9.0000 \\
X13 & 20 & 8.1000 & 1.9708 & 6.0000 & 10.0000 \\
X14 & 20 & 3.1705 & 0.3285 & 2.8700 & 3.7100 \\
X15 & 20 & 4.3731 & 0.1755 & 3.9799 & 4.6000 \\
\hline
\end{tabular}

Note: Own compilation based on the computations done on STATA (Version 12.0).

Table 3 suggests that all the selected variables in the study have equal number of 20 observations. This means that the panel is balanced with no missing observations. The results of the table also suggest that country's risk rating on threat of external conflict (X6) has the highest mean value of 9.8048. However the standard deviation of country's risk rating on business extent of disclosure index (X13) is the highest among the given variables, i.e., 1.9704. 


\subsection{Checking for stationarity}

In this case the stationarity test will be performed only on the FDI inflows because the other dependent variables are qualitative. Qualitative data loses its significance if it is made stationary.

To conduct this test for stationarity, Levin-Lin-Chu unit-root test is used. If the p-value is less than 0.05 , we reject the null hypothesis, i.e., panel contains unit root. In this case p-value came out to be more than 0.05 and thus null hypothesis could not be rejected implying that data contains unit root.

In order to solve the problem of unit root the ' $y$ ' series is converted into ' $y$ growth' series by taking natural $\log$ and then taking the first difference. After checking the data again for stationarity by using the Levin-Lin-Chu (2002) test, the problem of unit root was removed.

\subsection{Checking for multicollinearity}

The OLS methodology allows to check for the existence of multicollinearity in the model through the variance inflation factor (VIF). The literature shows that if the mean VIF is greater than 5, the model suffers from the problem of multicollinearity (Judge et al., 1982). One important way to resolve the problem of multicollinearity is to reduce the number of collinear variables until there are only unrelated variables remaining out of the set. Drop those variables whose VIF is more than 5 and tolerance level is lesser than 2 till the time all the VIFs of remaining variables in the model are lesser than 5. By calculating the VIF for all the fifteen variables under study the mean VIF came out to be higher than 5 as a result 11 variables were dropped and only 4 remained which were checked again for mean VIF.

Based on the results of the correlation matrix, VIF and tolerance level, highly correlated variables have been dropped and the remaining four uncorrelated variables were considered for the panel data regression model. The result of the alternative that is the best explanatory of the changes in FDI inflows is presented in Table 4.

Table 4 Variance Inflation Factor for dependent variables

\begin{tabular}{lccc}
\hline Variable & Name of the variable & VIF & $1 /$ VIF \\
\hline X2 & Country's risk rating on ethnic tensions & 4.4200 & 0.2261 \\
X3 & Logistics performance index & 3.5900 & 0.2788 \\
X1 & Country's risk rating on corruption & 1.4600 & 0.6832 \\
X4 & Gender parity index & 1.3200 & 0.7578 \\
Mean VIF & & 2.7000 & \\
\hline
\end{tabular}

Note: Own compilation based on the computations done on STATA (Version 12.0)

In Table 4, the mean VIF value as well as individual VIF is less than 5, thus no problem of multicollinearity is seen. 


\subsection{Specification of the model}

After testing the above assumptions, the general specification of the remaining parameters (dependent and independent variables) of the model in this study is as follows:

$$
\mathrm{Y}_{\mathrm{it}}=\alpha+\beta_{1} \mathrm{X} 1_{\mathrm{it}}+\beta_{2} \mathrm{X} 2_{\mathrm{it}}+\beta_{3} \mathrm{X} 3_{\mathrm{it}}+\beta_{4} \mathrm{X} 4_{\mathrm{it}}+\mu_{\mathrm{it}}
$$

where $Y_{\text {it }}$ refers to the log of FDI inflows (used in place of FDI net inflows) in the current USD for a country $\mathrm{i}$ (both India and China) at time period t. This is the dependent variable.

The right hand side of the specification model includes all the independent variables which are defined as follows:

$\mathrm{X} 1_{\text {it }}$ The country's risk rating on corruption for country $\mathrm{i}$ at time period $\mathrm{t}$.

$\mathrm{X} 2_{\mathrm{it}}$ The country's risk rating on ethnic tensions for a country $\mathrm{i}$ at time period $\mathrm{t}$.

$\mathrm{X} 3_{\text {it }}$ The logistics performance index, i.e., the score of the country on its ability to track and trace consignments for a country $i$ at time period $t$.

$\mathrm{X}_{\text {it }}$ The gender parity index for school enrolment at the tertiary level. GPI is the ratio of girls to boys enrolled at the tertiary level in public and private schools for a country $i$ at time period $t$.

$\mu_{\text {it }} \quad$ The stochastic disturbance term.

\subsection{Hypotheses development}

Based on the above assumptions, since only four variables were found not correlated with each other, thus only four hypotheses are being tested with the help of one dependent variable and four unrelated independent variables:

$\mathrm{H}_{01}$ Country's risk rating on corruption is not significant in determining FDI inflows of country i at time t.

$\mathrm{H}_{02}$ Country's risk rating on ethnic tensions is not significant in determining FDI inflows of country $i$ at time $t$.

$\mathrm{H}_{03}$ Logistics performance index is not significant in determining FDI inflows of country $\mathrm{i}$ at time $\mathrm{t}$.

$\mathrm{H}_{04}$ Gender parity index for school enrolment at the tertiary level is not significant in determining FDI inflows of country $i$ at time $t$.

\subsection{Statistical techniques}

In order to evaluate the potential determinants of FDI inflows for India and China as a group, panel data analysis (Balestra, 1992) has been applied. In this study along with the common constant/pooled OLS model, both fixed effects (FE) model and random effects (RE) model have also been used for exploring the key institutional determinants of FDI inflows into India and China. 
a The common constant model (also called as pooled OLS method)

Here the null hypothesis is that there is no difference between the constants (homogeneity), and thus, the pooled OLS method is applicable.

$$
\mathrm{H}_{0}=\alpha_{1}=\alpha_{2}=\alpha_{\mathrm{N}} \text {. }
$$

However, this case is practically not possible and has its own limitations. Thus it is important to include the fixed and random effects in the method for estimations.

b Fixed effects (FE) model

This model assumes that the constant is fixed over time for each group and that every group has a different constant

FE model can be explained as under:

$$
\mathrm{y}_{\mathrm{it}}=\alpha+\sum_{\mathrm{k}=1}^{\mathrm{k}} \mathrm{X}_{\mathrm{itk}} \beta_{\mathrm{k}}+\varepsilon_{\mathrm{it}}
$$

where

- $\quad \mathrm{i}=1,2, \ldots, \mathrm{N}$

- $\mathrm{t}=1,2, \ldots, \mathrm{T}$.

where $\mathrm{Y}_{\text {it }}$ represents the value of the dependent variable, that is, FDI inflows in cross-section i (two countries in our case); $\mathrm{T}$ is the length of time series, that is, 2007-2017; $\mathrm{k}$ is the number of independent variables explaining the dependent variable. The term $\alpha_{i}$ denotes unobserved country-specific effects that are assumed to be fixed over time and different across country $i . X_{i t}$ and $\beta$ represent the vectors of explanatory variables and their parameters respectively. The subscript $\mathrm{i}$ indicates individual countries, while $t$ shows different time periods. $\varepsilon_{\text {it }}$ represents the vector of the error component which is assumed to be independently distributed across $i$ and over $t$ with mean zero and variance $\sigma^{2}$.

c Random effects (re) model

This model of estimation assumes the constants for each section as random parameters rather than fixed. Hence, the constants tend to vary and do not remain fixed over time. In this case the model is defined as:

$$
\mathrm{y}_{\mathrm{it}}=\mu+\sum_{\mathrm{k}=1}^{\mathrm{k}} \mathrm{X}_{\mathrm{itk}} \beta_{\mathrm{k}}+\mathrm{v}_{\mathrm{it}}
$$

where

- $\quad \mathrm{i}=1,2, \ldots, \mathrm{N}$

- $\mathrm{t}=1,2, \ldots, \mathrm{T}$

- $\mathrm{V}_{\mathrm{it}}=\alpha_{\mathrm{i}}+\varepsilon_{\mathrm{it}}, \mathrm{t}=1, \ldots, \mathrm{T}$ are the composite errors.

For each $\mathrm{t}, \mathrm{v}_{\mathrm{it}}$ is the sum of the unobserved effect and an idiosyncratic error (Wooldridge, 2010). $\alpha_{\mathrm{i}}$ are assumed to be independently distributed across $i$, with mean zero and variance $\sigma_{\alpha}^{2}$ and uncorrelated with $\mathrm{X}_{\mathrm{it}}$ The error term $\varepsilon_{\mathrm{it}}$ is assumed to be independently distributed across $i$ and over $t$ with mean zero and variance $\sigma^{2}$. 
Finally, it can be seen that in the panel data analysis, the fixed effects model assumes that each country differs in its intercept term whereas the random effects model assumes that each country differs in its error term.

\subsection{Hausman specification test}

Hausman (1978) specification test must be used in order to find out the appropriate panel data model. Therefore, in such case following hypotheses are tested:

- $\quad$ Null hypothesis: $\mathrm{H}_{0}: \operatorname{Cov}\left(\alpha_{\mathrm{i}}, \mathrm{X}_{\mathrm{it}}\right)=0$, that is, random effect model is suitable, if null hypothesis is accepted.

- Alternate hypothesis: $\mathrm{H}_{\mathrm{a}}: \operatorname{Cov}\left(\alpha_{\mathrm{i}}, \mathrm{X}_{\mathrm{it}}\right) \neq 0$, that is, fixed effect model is suitable, if alternate hypothesis is accepted.

$$
\begin{aligned}
& \text { If } p<0.05 \rightarrow \mathrm{FE} \text { is suitable } \\
& \text { If } p>0.05 \rightarrow \mathrm{RE} \text { is suitable }
\end{aligned}
$$

where $p$ refers to the probability value of the test statistic. If $p$ value is larger than level of significance, then the null hypothesis cannot be rejected and therefore RE model is a more suitable model but if the $\mathrm{p}$ value is less than level of significance then the null hypothesis is rejected and FE model becomes more appropriate model to use.

After applying the three estimated models, i.e., OLS, FE and RE in the panel data analysis, we need to find out which model out of the three is a model of best fit. This is done by applying various statistical tests.

First, the study checks which model among the OLS regression and FE should be used. To check this, the standard F-test can be applied to see whether the model has fixed effects (i.e., different constants for each group). Second, we compare the FE model with the RE model to find out which of the two should be used. This can be done by using Hausman specification test. Third, to choose between the common constant model (OLS regression) and the RE model, Breusch and Pagan (1980) Lagrange multiplier (LM) test is computed.

\section{Empirical results and discussion}

Table 5 shows the correlation matrix of the variables chosen for study.

Table 5 Correlation

\begin{tabular}{lccccc}
\hline & $Y$ & $X 1$ & $X 2$ & $X 3$ & $X 4$ \\
\hline $\mathrm{Y}$ & 1.0000 & & & & \\
$\mathrm{X} 1$ & -0.0884 & 1.0000 & & & \\
$\mathrm{X} 2$ & -0.1225 & -0.5522 & 1.0000 & & \\
$\mathrm{X} 3$ & 0.0803 & 0.4217 & -0.8471 & 1.0000 & \\
$\mathrm{X} 4$ & -0.1935 & -0.3231 & 0.4868 & -0.4295 & 1.0000 \\
\hline
\end{tabular}

Table 5 shows the direction in which FDI inflows move in relation to the selected determinants. From the table, it can be seen that only variable X3 (logistics performance 
index: ability to track and trace consignments) is showing a positive sign meaning a direct relationship with the FDI inflows. All the other variables X1 (country's score on corruption), X2 (country's score on ethnic tensions) and X4 (gender parity index for school enrolment at the tertiary level) are negatively correlated with FDI inflows, i.e., an increase in the country's score on any of these variables will adversely affect the FDI inflows for that country. Further, the results in Table 5 display that X2 and X3 are correlated (correlation is -0.8471 ), however when the significance of this correlation was checked, it was found to be insignificant, i.e., less than 0.05 . Moreover, the results in Table 4 earlier clearly showed the mean VIF value to be much lesser than 5 , inferring that none of the independent variables are found to be correlated with each other, hence, solving the multicollinearity problem in the model.

In order to capture the distribution of FDI across India and China over a period of 10 years the estimates were generated using the following panel data techniques:

1 common constant (OLS regression) model

2 FE model

3 RE model.

The estimation results of all the three models are explained in Table 6 .

Table 6 Determinants of FDI inflows as per the three models of panel data analysis

\begin{tabular}{|c|c|c|c|}
\hline \multicolumn{4}{|c|}{ Dependent variable: FDI inflows } \\
\hline Independent variables & $\begin{array}{l}\text { Common constant } \\
\text { model }(O L S)\end{array}$ & $\begin{array}{l}\text { Fixed effects } \\
\text { model (FE) }\end{array}$ & $\begin{array}{l}\text { Random effects } \\
\text { model (RE) }\end{array}$ \\
\hline $\mathrm{X} 1$ & $\begin{array}{l}-6.0894 \\
(-4.41)\end{array}$ & $\begin{array}{c}-0.35834 \\
(-0.85)\end{array}$ & $\begin{array}{r}-0.3369 \\
{[-0.83]}\end{array}$ \\
\hline $\mathrm{X} 2$ & $\begin{array}{l}0.5131 \\
(2.00)\end{array}$ & $\begin{array}{c}-0.0233 \\
(-0.06)\end{array}$ & $\begin{array}{c}-0.1142 \\
{[-0.54]}\end{array}$ \\
\hline $\mathrm{X} 3$ & $\begin{array}{c}-7.5022 \\
(-3.13)\end{array}$ & $\begin{array}{c}-0.3932 \\
(-0.41)\end{array}$ & $\begin{array}{l}-0.2055 \\
{[-0.29]}\end{array}$ \\
\hline $\mathrm{X} 4$ & $\begin{array}{l}6.2091 \\
(1.76)\end{array}$ & $\begin{array}{l}-0.0881 \\
(-0.30)\end{array}$ & $\begin{array}{c}-1.4804 \\
{[-0.69]}\end{array}$ \\
\hline Mean VIF & 2.95 & - & - \\
\hline F-Test & - & $0.26^{*}$ & - \\
\hline Wald chi-square & - & - & 5.05 \\
\hline $\mathrm{R}^{2}$ within & - & 0.0699 & 0.0638 \\
\hline $\mathrm{R}^{2}$ between & - & 1.0000 & 1.0000 \\
\hline $\mathrm{R}^{2}$ overall & - & 0.0079 & 0.0833 \\
\hline Mean VIF & & \multicolumn{2}{|c|}{2.17} \\
\hline Hausman test (p-value) & & \multicolumn{2}{|c|}{$0.10(0.9989)$} \\
\hline $\begin{array}{l}\text { Breusch-Pagan Lagrange } \\
\text { multiplier (LM) test: } \\
\operatorname{Var}(\mathrm{u})=0\end{array}$ & - & - & $\begin{array}{c}\text { Chi-square }=0.00 \\
\text { Prob. }>\text { chi-square } \\
\quad=1.0000\end{array}$ \\
\hline
\end{tabular}

Notes: Parentheses () and [] show the t-value and z-statistics respectively.

$*$ denotes the significance at $5 \%$. 
From Table 6, it can be seen that the first column (common constant model) shows the estimation results for the regression equation. However the OLS methodology is only useful if the dataset is assumed to be homogeneous, that is, there is no difference between the estimated cross sections (India and China in our case). Therefore, this model is quite restrictive; however it allows us to check for the existence of multicollinearity in the model through the variance inflation factor (VIF). In Table 6, the mean VIF from OLS is found to be 2.95 which imply that there is no indication of multicollinearity problem in the model considered. Also the F-test indicates that the null hypothesis (OLS model) is rejected and therefore FE model is preferred to common constant (OLS) model.

The third and fourth columns of the table respectively show the results of the FE and RE model. The next choice is between the FE and RE model. In order to select one of the two models, Hausman specification test was conducted. The test gave a chi-square value of 0.10 which was not significant at $5 \%$ significance level and therefore RE model is chosen over the FE model.

For comparing the RE model with the common constant model, Breusch-Pagan Lagrange multiplier test was conducted which revealed that the Prob $>\chi^{2}$ was more than 0.05 and hence we failed to reject the null hypothesis that the variances across the two countries are same due to which RE model was not appropriate and OLS model should be used. But we are still going to use the RE model instead of the OLS model because of two reasons. First, the results of the OLS model were found to be similar to that of the RE model and second because the Hausman specification test also favoured the RE model in comparison with FE model. Moreover the common constant model assumes homogeneity in the datasets, which is practically not possible. Therefore, it was decided to drop the common constant model and not to report its results any further in the study.

\subsection{Residual diagnostic testing}

Modified Wald test for group-wise heteroskedasticity for both the FE and RE models was testes which has a chi-square value of 5.05 which is not significant at $5 \%$ significance level. Thus, we cannot reject the null hypothesis (homoscedasticity or constant variance) and therefore conclude that the models are not suffering from the problem of heteroskedasticity.

In order to test the cross-sectional dependence/contemporaneous correlation among the residuals, Breusch-Pagan Lagrange multiplier test of independence was used for the FE and RE models which showed that the chi-square distribution is 0.024 with a $p$ value of 0.8758 so the chi-square distribution is not significant at 5\% significance level and therefore we cannot reject the null hypothesis that is, there is no cross-sectional dependence or residuals across countries are not correlated.

Lastly, the test for serial correlation is conducted where the F-statistic comes out to be 0.231 which is again not significant at 0.05 level so we cannot reject the null hypothesis and conclude that the residuals do not have first-order autocorrelation.

From the above results we can see that although both the models do not suffer from the problem of heteroskedasticity, neither do they violate the assumption of no autocorrelation among the residuals but still in order to derive the model of best fit the robust models of FE and RE will be used. For FE and RE models, the cluster option in STATA can be applied along with the regression command to produce robust standard 
error estimates for linear panel models. The results of the modified model are presented in Table 7.

The empirical results of the RE model as presented in Table 7 shows that country's risk rating on corruption (X1) is a significant determinant of FDI inflows in India and China and it is negatively affecting the FDI inflows. It implies that as the scores on corruption for the countries go up, the resultant effect on FDI inflows is negative because MNCs or any individual would not like to invest in a country with high levels of corruption because it has a negative impact on the nations' economic growth. This might act as a demotivating factor for the investors while analysing the alternative of making long term investments in Asian countries like India and China.

Table 7 Determinants of FDI Inflows as per both the modified models of panel data analysis

\begin{tabular}{|c|c|c|}
\hline \multicolumn{3}{|c|}{ Dependent variable: FDI inflows } \\
\hline $\begin{array}{l}\text { Independent } \\
\text { variables }\end{array}$ & $\begin{array}{l}\text { Fixed effects model-cluster option } \\
\text { (FE) }\end{array}$ & $\begin{array}{l}\text { Random effects model-cluster option } \\
\text { (RE) }\end{array}$ \\
\hline Intercept & $\begin{array}{l}3.2319 \\
(0.74)\end{array}$ & $\begin{array}{c}3.47875 \\
{[0.74]}\end{array}$ \\
\hline $\mathrm{X} 1$ & $\begin{array}{l}-0.3583 \\
(-1.15)\end{array}$ & $\begin{array}{l}-0.3369 \\
{[-5.15]^{*}}\end{array}$ \\
\hline $\mathrm{X} 2$ & $\begin{array}{c}-0.0233 \\
(-0.06)\end{array}$ & $\begin{array}{c}-0.1142 \\
{[-0.39]}\end{array}$ \\
\hline $\mathrm{X} 3$ & $\begin{array}{l}-0.3932 \\
(-0.31)\end{array}$ & $\begin{array}{c}-0.2056 \\
{[-0.17]}\end{array}$ \\
\hline $\mathrm{X} 4$ & $\begin{array}{l}-0.8812 \\
(-0.32)\end{array}$ & $\begin{array}{l}-1.4804 \\
{[-5.46]^{*}}\end{array}$ \\
\hline $\mathrm{R}^{2}$ within & - & 0.0638 \\
\hline $\mathrm{R}^{2}$ between & - & 1.0000 \\
\hline $\mathrm{R}^{2}$ overall & - & 0.0833 \\
\hline
\end{tabular}

Notes: Parentheses () and [] show the $t$-value and $z$-statistics, respectively.

* denotes significance at $5 \%$ level.

Country's risk rating on gender parity index for school enrolment at the tertiary level (X4) is also significant in determining FDI inflows. However the negative coefficient shows the inverse relationship between the variable and FDI inflows. This might be because although in recent years the ratings of both the countries have gone up with regards to GPI for school enrolment which means that the countries are performing good on this front but there is still a lot of scope for improvement. The increase in ratings is not sufficient to attract FDI towards these countries. Both these determinants are statistically significant at $5 \%$ level of significance.

Besides, the result shows that the other variables like the country's risk rating on ethnic tensions and the country's risk rating on logistics performance index for the ability to track and trace consignments have insignificant coefficient values implying that these are not very relevant for impacting FDI inflows in both India and China.

It can also be asserted from the findings that the determinants are behaving in the same direction as expected in other developing countries of the world and are extremely useful (95\% confidence level) in attracting FDI inflows in India and China (The result confirm the previous studies conducted by Sabir et al. (2019), Paul and Jadhav (2019), 
Kurul and Yalta (2017), Esew and Yaroson (2014), Malhotra et al. (2014), Fakher (2014), Fiodendji (2013), Bénassy-Quéré et al. (2007), Daude and Stein (2007), among many others.

The theories existing in the international business environment that determine the movement of FDI flows to a specific country support the findings of the study (Dunning and Narula, 2003; Paul and Jadhav, 2019).

\section{Conclusions and implications}

The findings indicate that both the Governments of India and China must put efforts in reducing the level of corruption and improving the ratio of females to males getting enrolled in school at the tertiary level in order to attract more FDI.

As per an article published by the World Bank (Combating Corruption, 2018):

"Successful anti-corruption efforts are often led by a 'coalition of concerned' politicians and senior government officials, the private sector, and by citizens, communities, and civil society organizations. Increasingly, successfully addressing corruption will require the concerted attention of both governments and businesses, as well as the use of the latest advanced technologies to capture, analyze, and share data to prevent, detect, and deter corrupt behavior."

Both the countries may also take lessons from another emerging economy like Brazil which has conducted a variety of data analytics trial in the northeastern state of Ceará where it could explore how surveys on mobile data exchanges and also some scientific techniques applied on the administrative data can be used to unveil suspicious trends of deals between public servants and general public. They used these surveys along with the administrative data collected from time to time from these places to administer the hospital services and environmental licensing process. With the help of such experiments, they were effectively able to identify corruption red flags.

With respect to the other significant determinant impacting the FDI inflows of India and China, i.e., gender parity index, education reforms are the need of the hour. Both the countries should not just focus on gender parity but also on gender dynamics. In other words, the quality of education should be reformed so as to make better and bigger opportunities available to both girls and boys. In a world of advancements at the pace of wink of eye, it is the need of the hour for any emerging country to keep up the pace of technological advancements and inculcate them into the curriculum imparted at any level of education. Also, the traditional model of school education can also be seen as evolving and intervention of modern technologies can be perceived to be a boon for the enrolment rates of students (both girls and boys) who cannot access schools due to their approachability and proximity. Both the governments should also make provisions to render essential public services such as education and health to maximum parts of the population for the overall economic development of their nations. Additionally, the government of both these countries The government should also allocate more capital in their budgets for the implementation of programs for improving physical infrastructure which in turn will boost the gross enrolment rates in schools and other educational institutions. Both Indian and Chinese Governments should lay equal emphasis on the need to provide more support to rural areas and less-developed regions of their countries signalling a positive growth impetus to the foreign investors wanting to invest in them. 
In addition to the above two determinants, both the countries should put individual efforts also to have more integration among each other. Both these countries are classified as emerging economies and hence there is a lot of scope for improvement on various fronts in order to drive FDIs to various sectors. Poor institutional quality is the biggest challenge for these countries.

In case of China, besides the factors identified in the study, other factors like friendly business climate, structural changes, better infrastructure facilities to promote exports, strategic policy initiatives of providing economic freedom, and flexible laws can also be the driving forces for attracting FDI. Similarly while India has risen due to its human capital, size of the market, market growth rate, and stability of political systems, apart from the factors identified in the study, to enhance FDI inflows, the policy makers need to ensure more economic and political stability, better infrastructure facility, a peaceful environment having a proper law and order mechanism, and reduce the external liabilities.

\subsection{Theoretical implications}

- The present study differs from the earlier studies in the existing literature by including qualitative determinants not studied earlier by other researchers in the context of emerging economies, i.e., India and China.

- This study also has an important theoretical contribution for the researchers who might take this study further and use the proposed models of FDI for other emerging or group of emerging economies like BRICS (Brazil, Russia, India, China and South Africa), PIN (Pakistan, Indonesia, Nigeria), MINT (Mexico, Indonesia, Nigeria, Turkey) etc.

\subsection{Managerial implications}

- This study enhances knowledge of the determinants of FDI in India and China. Firms from these emerging markets may better understand the factors that influence their internationalisation process (in terms of qualitative factors).

- This study helps the governments of other group of emerging countries such as PIN (Pakistan, Indonesia, and Nigeria); MINT (Mexico, Indonesia, Nigeria and Turkey); CIVETS (Colombia, Indonesia, Vietnam, Egypt, Turkey and South Africa); Next Eleven (Bangladesh, Egypt, Indonesia, Iran, Mexico, Nigeria, Pakistan, Philippines, Turkey, South Korea and Vietnam) which can follow the path of these two most emerging economies in growth and formulate policies to attract FDI accordingly.

- At the enterprise level, it helps MNCs in understanding Indian and Chinese markets and formulating entry and growth strategies in these most emerging countries of the world.

It can be concluded that this study is conducted with an intention to help the policy makers in these countries who can make strategic decisions about those specific areas of concern only where their country is lagging (in terms of institutional quality) and channellise the efforts of their governments to turn this dream into reality- the dream to become supreme powers in the world economy. 


\section{References}

Akpan, U.S., Isihak, S.R. and Asongu, S.A. (2014) Determinants of Foreign Direct Investment in Fast-Growing Economies: A Study of BRICS and MINT, AGDI Working Paper No. WP/14/002, African Governance and Development Institute, Research Department.

Amendolagine, V., Presbitero, A.F., Rabellotti, R. and Sanfilippo, M. (2019) 'Local sourcing in developing countries: the role of foreign direct investments and global value chains', World Development, Vol. 113, pp.73-88.

Arbatli, E. (2011) Economic Policies and FDI Inflows to Emerging Market Economies, Working Paper 11/192, International Monetary Fund [online] https://www.imf.org/en/Publications/WP/ Issues/2016/12/31/Economic-Policies-and-FDI-Inflows-to-Emerging-Market-Economies25160 (accessed 1 May 2017).

Asiedu, E. (2002) 'On the determinants of foreign direct investment to developing countries: is Africa different?', World Development, Vol. 30, No. 1, pp.107-119.

Assadzadeh, A. and Pourqoly, J. (2013) 'The relationship between foreign direct investment, institutional quality and poverty: case of MENA countries', Journal of Economics, Business and Management, Vol. 1, No. 2, pp.161-165.

Balestra, P. (1992) 'Introduction to linear models for panel data', The Econometrics of Panel Data, pp.21-29, Springer, Netherlands.

Basu, S., Deepthi, D. and Reddy, J. (2011) Country Risk Analysis in Emerging Markets: The Indian Example, Working Paper No. 326, pp.1-16, Indian Institute of Management, Bangalore.

Bénassy-Quéré, A., Coupet, M. and Mayer, T. (2007) 'Institutional determinants of foreign direct investment', World Economy, Vol. 30. No. 5, pp.764-782, DOI: 10.1111/j.1467-9701. 2007.01022.x.

Bergsman, J., Broadman, H.G. and Drebentsov, V. (1999) 'Improving Russia's foreign direct investment policy regime', in Broadman, H.G. (Ed.): Russian Trade Policy Reform for WTO Accession, The World Bank, Washington, DC.

Bon, N.V. (2014), 'Effects of institutional quality on FDI in provinces of Vietnam', Journal of Economic Development, Vol. 22, No. 3, pp.26-45.

Breusch, T.S. and Pagan, A.R. (1980) 'The LM test and its applications to model specification in econometrics', Review of Economic Studies, Vol. 47, No. 1, pp.239-254.

Busse, M. and Hefeker, C. (2005) Political Risk, Institutions and Foreign Direct Investment, HWWA Discussion Paper No. 315, SSRN [online] http://dx.doi.org/10.2139/ssrn.704283 (accessed 26 June 2018).

Chaib, P.B. and Siham, M. (2014), 'The impact of institutional quality in attracting foreign direct investment in Algeria', Topics in Middle Eastern and African Economies, Vol. 16, No. 2, pp.142-163.

Daude, C. and Stein, E. (2007) 'The quality of institutions and foreign direct investment', Economics \& Politics, Vol. 19, No. 3, pp.317-344.

David, A., Bastos, F.R. and Mills, M. (2011) Post-conflict Recovery: Institutions, Aid or Luck?, Working Paper 11/149, International Monetary Fund [online] http://www.imf.org/ external/pubs/cat/longres.aspx?sk=24993 (accessed 1 May 2017).

Dunning, J. and Narula, R. (2003) Foreign Direct Investment and Governments: Catalysts for Economic Restructuring, Routledge, UK.

Eregha, P.B. (2019) 'Exchange rate, uncertainty and foreign direct investment inflow in West African monetary zone', Global Business Review, Vol. 20, No. 1, pp.1-12.

Esew, N.G. and Yaroson, E. (2014) 'Institutional quality and foreign direct investment (FDI) in Nigeria: a prognosis', IOSR Journal of Humanities and Social Science, Vol. 19, No. 6, pp.37-45.

Fakher, A. (2014) 'Quality of institutions and integration in the world economy: applied study on Egypt', East-West Journal of Economics and Business, Vol. 17, No. 2, pp.69-96. 
Fanbasten, N. and Escobar, A.G. (2016) Determinants of Foreign Direct Investment: A Panel Data Analysis of the MINT Countries, Master's thesis, Department of Business Studies, Uppsala University [online] http://uu.diva-portal.org/smash/get/diva2:939333/FULLTEXT01.pdf (accessed 26 September 2019).

Fiodendji, D.K. (2013) Do Institutions Quality affect FD inflows in Sub Saharan African Countries?, MPRA Paper No. 57414 [online] http://mpra.ub.uni-muenchen.de/57414/ (accessed 26 September 2019).

Hausman, J.A. (1978) 'Specification tests in econometrics', Econometrica, Vol. 46, No. 6, pp.1251-1271.

Hu, Y. (2007) Foreign Direct Investment in China and India: Development Experiences and Determinants in a Comparative Perspective, Dissertation in partial fulfilment of the requirements of the degree of MSc in China in Comparative Perspectives (Anthropology Department).

International Country Risk Guide (ICRG) Methodology [online] http:/www.prsgroup.com/ ICRG_methodology.aspx (accessed 18 May 2019).

International Monetary Fund (2003) Foreign Direct Investment Trends and Statistics Report [online] https://www.imf.org/external>sta>fdi>eng>2003].

Jadhav, P. (2012) 'Determinants of foreign direct investment in BRICS economies: analysis of economic, institutional and political factor', Procedia - Social and Behavioral Sciences, Vol. 37, pp.5-14.

Jones, A., Fallon, G. and Golov, R. (2000) 'Obstacles to foreign direct investment in Russia', European Business Review, Vol. 12, No. 4, pp.187-197 [online] https://doi.org/10.1108/ 09555340010336871.

Judge, G.G., Hill, R.C., Griffiths, W.E., Lütkepohl, H. and Lee, T.C. (1982) Introduction to the Theory and Practice of Econometrics, John Wiley \& Sons, New York.

Kinoshita, Y. (2011) Sectoral Composition of FDI and External Vulnerability in Eastern Europe, Working Paper 11/123, International Monetary Fund [online] https://www.imf.org/en/ Publications/WP/Issues/2016/12/31/Sectoral-Composition-of-Foreign-Direct-Investment-andExternal-Vulnerability-in-Eastern-24886 (accessed 1 May 2017).

Kurul, Z., and Yalta, A.Y. (2017) 'Relationship between institutional factors and FDI flows in developing countries: new evidence from dynamic panel estimation', Economies, Vol. 5, No. 2, pp.1-17, doi: ARTN 17 10.3390/economies5020017

Levin, A., Lin, C-F. and Chu, C-S.J. (2002) 'Unit root tests in panel data: asymptotic and finite-sample properties', Journal of Econometrics, Vol. 108, pp.1-24.

Mahbub, T. and Jongwanich, J. (2019) 'Determinants of foreign direct investment (FDI) in the power sector: a case study of Bangladesh', Energy Strategy Reviews, April, Vol. 24, pp.178-192 [online] https://doi.org/10.1016/j.esr.2019.03.001.

Malhotra, D.K., Russow, L. and Singh, R. (2014) 'Determinants of foreign direct investment in Brazil, Russia, India and China', International Journal of Business, Accounting, and Finance, Vol. 8, No. 1, pp.130-148.

Maskus, K.E. (2000) Intellectual Property Rights and Foreign Direct Investment, Working Paper No. 22, Centre for International Economic Studies, SSRN [online] http://dx.doi.org/10.2139/ ssrn.231122] (accessed 26 June 2018).

Mathur, A. and Singh, K. (2013) 'Foreign direct investment, corruption and democracy', Applied Economics, Vol. 45, No. 8, pp.991-1002.

Mishra, A. and Daly, K. (2007) 'The impact of institutions quality on foreign direct investment: recent evidence from Asian countries', International Review of Business Research Papers, Vol. 3, No. 2, pp.233-245.

Miyamoto, K. (2003) Human Capital Formation and Foreign Direct Investment in Developing Countries, Paper No. 211, Organisation for Economic Co-operation and Development (OECD), SSRN [online] http://dx.doi.org/10.2139/ssrn.668505 (accessed 26 June 2018). 
Musila, J.W. and Sigue, S.P. (2006) 'Accelerating foreign direct investment flow to Africa: from policy statements to successful strategies', Managerial Finance, Vol. 32, No. 7, pp.577-593.

Nagaraj, R. (2003) 'Foreign direct investment in India in the 1990s: trends and Issues', Economic and Political Weekly, Vol. 38, No. 17, pp.1701-1712.

Pao, H.T. and Tsai, C.M. (2011) 'Multivariate granger causality between $\mathrm{CO}_{2}$ emissions, energy consumption, FDI (foreign direct investment) and GDP (gross domestic product): evidence from a panel of BRIC (Brazil, Russian Federation, India, and China) countries', Energy, Vol. 36, No. 1, pp.685-693.

Paul, J. and Jadhav, P. (2019) 'Institutional determinants of foreign direct investment inflows: evidence from emerging markets', International Journal of Emerging Markets, in press [online] https://doi.org/10.1108/IJOEM-11-2018-0590.

Peres, M., Ameer, W. and Xu, H. (2018) 'The impact of institutional quality on foreign direct investment inflows: evidence for developed and developing countries', Economic Research Ekonomska Istraživanja, Vol. 31, No. 1, pp.626-644 [online] https://doi.org/10.1080/ 1331677X.2018.1438906.

Popa, S. (2012) 'The influence of the country risk rating on the foreign direct investment inflows in Romania', International Journal of Economic Sciences, Vol. 1, No. 2, pp.93-116.

Popovich, A. (2007) Investing in Emerging Markets: Finding out How Political Risk Influences FDI in Russia, SSRN [online] http://dx.doi.org/10.2139/ssrn.996414] (accessed 26 June 2018).

Rehman, A.S. (2009) 'Studying determinants of FDI in Pakistan', Proceedings of 2nd International Conference on Business Management, pp.1-17.

Sabir, S., Rafiq, A. and Abbas, K. (2019) 'Institutions and FDI: evidence from developed and developing countries', Financial Innovation, Vol. 5, No. 8, pp.1-20 [online] https://doi.org/ 10.1186/s40854-019-0123-7

Samara, S. (2012) Foreign Direct Investment and Country Risk: What Kind of Interaction?, pp.1-40, Department of Balkan, Slavic and Oriental Studies, University of Macedonia.

Savoiu, G., Dinu, V. and Ciuca, S. (2013) 'Foreign direct investment based on country risk and other macroeconomic factors: econometric models for Romanian economy', Romanian Journal of Economic Forecasting, Vol. 16, No. 1, pp.39-61.

Seyoum, B. and Manyak, T.G. (2009) 'The impact of public and private sector transparency on foreign direct investment in developing countries', Critical Perspectives on International Business, Vol. 5, No. 3, pp.187-206.

Talamo, G. (2011) 'Corporate governance and capital flows', Corporate Governance, Vol. 11, No. 3, pp.228-243.

The World Bank (2018) Combating Corruption [online] https://www.worldbank.org/en/topic/ governance/brief/anti-corruption (accessed 26 September 2019).

Walsh, J.P. and Yu, J. (2010) Determinants of Foreign Direct Investment: A Sectoral and Institutional Approach, WP/10/187, International Monetary Fund Working Paper, Asia Pacific Department.

Wint, A.G. and Williams, D.A. (2002) 'Attracting FDI to developing countries: a changing role for government?', International Journal of Public Sector Management, Vol. 15, No. 5, pp.361-374.

Wong, M.F., Fai, C.K., Yee, Y.C. and Cheng, L.S. (2019) 'Macroeconomic policy and exchange rate impacts on the foreign direct investment in ASEAN economies', International Journal of Economic Policy in Emerging Economies, Vol. 12, No. 1, pp.1-10.

Wooldridge, J.M. (2010) Econometric Analysis of Cross Section and Panel Data, MIT Press, Massachusetts (United States).

World Development Indicators 2019 Database, World Bank [online] http://data.worldbank.org/ data-catalog/world-development-indicators (accessed 3 June 2019). 
Yingxi, M. and Hung, J.H. (2018) 'Inward FDI and economic growth: a comparative analysis of China versus India', The State of China's State Capitalism, pp.239-262, Palgrave Macmillan, Singapore.

Zebregs, M.H. and Tseng, M.W. (2002) Foreign Direct Investment in China: Some Lessons for Other Countries, Nos. 2-3, International Monetary Fund.

Zheng, Y. (2019), 'Foreign direct investment in China', Handbook on the International Political Economy of China, Vol. 8, No. 9, pp.61. 